Virginija Švedienė

Прегледни рад

Panevėžys County

UDK 027.54(474.5)"1912/2017"

Gabrielè Petkevičaitè-Bitè

https://doi.org/10.18485/bibliotekar.2019.61.1.4

Public Library, Lithuania

virginija.svediene@pavb.lt

\title{
PANEVĖŽYS COUNTY GABRIELĖ PETKEVIČAITĖ-BITE் PUBLIC LIBRARY: INNOVATIONS AND TRADITIONS
}

\begin{abstract}
Panevėžys County Gabrielè Petkevičaitè-Bitè Public Library is the largest public library in the northeastern region of Lithuania, which celebrated its $95^{\text {th }}$ anniversary in 2017. It is the principal library in this region with the largest universal fund, famous for traditions of successful cultural projects. It is an important regional centre of culture and education. The vision of the Library is a modern centre of the library innovations in the region, providing an attractive environment and equal possibilities for learning and creation. Today, the Library pays a special attention to the development of quality educational programs and their application to various age groups. One of the main priorities is the improvement of digital literacy, but without losing the ultimate mission of the Library, i.e. promotion of reading. The Library creates spaces attractive for the users' self-expression, where traditional activities and education based on modern technologies harmoniously blend.
\end{abstract}

Keywords: Lithuania, library, innovation, tradition, education.

\section{History and mission}

Panevėžys County Gabrielè Petkevičaitè-Bitè Public Library is the first state library and the oldest state cultural institution in Panevežys, established in 1922, opened as a branch of the Central State Book Store. At that time, there were 1,783 books in its funds, all newspapers and magazines published in Lithuania, a few newspapers arriving from Germany and the USA. Today, the Library contains over half a million publications. Over 500,000 readers and more than 300,000 virtual readers visit it annually. The Library employs over 100 workers. 
Panevezžys County Gabrielè Petkevičaitė-Bitè Public Library is the principal modern library with the largest universal fund in the northeastern region of Lithuania, developing diverse cultural activities. ${ }^{1}$ For the population of Panevezžys and its county, the Library is attractive due to its versatility and multifunctionality. It is an important and strong centre of regional culture and education, where competence and creativity of people are continualy developed.

Having covered an interesting and purposeful historical road, Panevežys County Gabrielè Petkevičaité-Bite Public Library of today is modern, innovative, and open, providing not only convenient and cosy physical space for the visitors, but also motivating them to develop independently and implement their creative ideas. The Library strives that the visitors do not only receive quality and reliable information, find attractive and equal possibilities for learning and creation, and a convenient personal space for work and leisure, but also feel spiritually safe and elated.

\section{Educational programs for implementation of the vision in a modern library}

Nowadays, various activities are arranged in the spaces of public libraries worldwide, which would have been called untraditional in the past. The environment of the dynamic, creative information society determines new user needs and they stimulate the libraries to look for innovative forms and means to echo such needs, to create new services. The society sees and approves such alterations. The user target group also undergoes changes: if earlier efforts had been orientated to the audiences of children and adults, now with new practices the consideration is given to families with children, young people, and seniors.

Gabrielè Petkevičaitè-Bite Public Library is remarkable and attractive by its on-going cultural projects and educative programs, information services based on modern technologies. ${ }^{2}$ Libraries in general have a tendency to become social spaces, even by their architecture, so Gabrielè Petkevičaitè-Bitè Public Library is constantly changing, making experiments both in its physical structure and in the field of services.

1 Virginija Švedienè, „Kultūros misionieriai”. Tarp knygu nr. 7-8 (2018): 31-33.

2 Greta Ratkutė, „Projektas, skatinantis pažinti savo kraštą”. Tarp knygų nr. 11 (2018): 11. 
During the current decade, a particular attention has been paid to the implementation of the vision for the Library as modern, attractive for self-expression and association, and promotion of studies. Gabrielè Petkevičaitè-Bité Public Library pays a special attention to education of children and youth. A successful project is realized each year inviting school children to summer reading and creativity camps, where they try to find interesting ways to view books from a different angle, unconventionally. With assistance of professional painters and IT specialists, the campers learn how to use the program Comics head and create drawings for comic books in their tablets. The bookbinding specialists are invited to the educative classes, where children are taught how to bind the book with already produced comics. After the summer camp, the Department of Children's Literature at the Library issues a book of comics, which contains colourful works of all campers.

The successful and popular educational program Etno kilimas (Ethnic carpet) allows children and youth to visit interactively (using mobile apps) natural monuments of Aukštaitija (region where Panevėžys county is located), listen to stories about mounds, sacral places, lakes, large stones, by which these mysterious places are connected, and get to know their country not only from the handbook. This is an attractive and innovative service, raising children and youth's public spirit, motivating interest in history of their region and country. The idea for Panevėžys librarians to produce such educational program emerged after a visit to the library Dokk1 in Aarhus (Denmark), where many services (in particular for children) are play-based. In cooperation with Panevėžys Local Lore Museum, the most important natural monuments in Aukštaitija have been selected. Six libraries from Panevežys region became partners in the project. In the implementation of the project, members of various art industries took part, who designed the mobile apps, illustrations on the carpet, recorded stories, produced place setting, and access applications. The interactive learning tools produced within a project are executed by Gabrielè Petkevičaitė-Bitè Public Library or educators of the library visit schools, also together with specialists of the departments of children's literature from regional libraries. This educational program is presented in such mass events as Vilnius Book Fair, Expo Aukštaitija, and Schools Fair. In 2017, by the decision of the Lithuanian Council of Culture, Etno kilimas was declared the best in the project group Atminties institucijos. Inovatyviu paslaugu kürimas (Institutions of the Memory. Development of Innovative Services) in Lithuania.

In 2016, the community of Gabrielè Petkevičaitè-Bite Public Library was the first in Lithuania to join the worldwide popular social technological edu- 
cation project Coder $\mathrm{Dojo}^{3}$, motivating youth, children and their parents to produce applications, websites and by other interesting methods to learn more about the world of technologies and probably to integrate the vocational future with it. Constantly operating Coder Dojo club, which arranges regular programming training for children and youth, is located in the Library. Annually, Gabrielè Petkevičaitè-Bitè Public Library supports the initiative of the European programming week (Euro Code Week), when thousands of events worldwide provide knowledge in programming and invite to embrace continuous learning in libraries and individually.

The Library is implementing the project Kompiuterines grafikos paslaptys (Secrets of Computer Graphics). The users' creative and computer skills are developed through technology. New modern computerized working places with a personal computer and a graphical tablet have been produced. Using a graphic tablet, the user can draw on the computer with his hand and not with the mouse. Such classes provide the Library users with a possibility to turn simple drawing and writing on the paper into the digital process. Thus, users of different age can compare the principles of conventional and digital drawing and writing, master their computer skills and abilities to produce a new digital content, and learn to analyse the creative process of graphical information. It is important that graphical tablets react to the soft movements of fingers, so drawing and production of simple graphical figures also become a reality for disabled persons and senior people.

Attractive and involving robotics classes for children are organized more and more often in the Lithuanian libraries. Gabrielè Petkevičaitė-Bitè Public Library is not an exeption. It organizes classes for children aged 8-12 years, who are interested how to design and program LEGO Brainstorm EV3 robot models, and to resolve tasks of various complexity. By playing and designing, children learn basics of the robot design and programming, get acquainted with the laws of mechanics and physics, strengthen skills of orientation in the space and knowledge in maths. Gabrielè Petkevičaitè-Bitė Public Library not only arranges the robotics classes, but also has founded a team of robotics enthusiasts participating and prize-winning in the regional First LEGO League competitions. Panevėžys City has chosen the strategic robotics specialization for further regional expansion and determined an ambitious target to become one of the

Per Lietuva ima ristis Coder Dojo, pasaulinès iniciatyvos, mokančios vaikus programuoti, banga [interaktyvus, žiūreta 2019 m. balandžio 25 d.]. Prieiga per internetą: https://aina.lt/per-lietuvaima-ristis-coder-dojo-pasaulines-iniciatyvos-mokancios-vaikus-programuoti-banga/. 
strongest robotics and automation centres in the Northeast Europe. Therefore, Gabrielè Petkevičaité-Bite Public Library, by motivating children and youth to take interest in robotics, remarkably contributes to the implementation of the ambition.

The personnel of the Library create educational programmes to improve information, communication and team work skills for disabled people. Accordingly, the education program in robotics has been produced, which objective is to present programming and robot design techniques for children and youth under 16. LEGO Brainstorm software is employed, which can be easily designed and controlled by children and youth with activity and attention concentration disorders or other slight physical problems. Education programs teaching children to design and program robots and to perform involving creative tasks are conducted by the library staff not only in Panevėžys, but also in Panevėžys region, because Gabrielè Petkevičaitè-Bitè Public Library is a competence centre for 12 municipal libraries in Panevėžys region.

In January 2019, the Library opened the door for the Sensory Space. It is a modern educative space, where new generation sensory equipment can be tested, thus stimulating senses and producing curative, training, and stimulating environment. The Library personnel is doing its best to make the Sensory Space attractive for children with special needs and their parents, and other visitors of the Library. The equipment employed in the Sensory Space is unique for now and offers really wide application possibilities. Using a special tablet, a visitor of the Space, or a specialist working with a group, can produce a desirable environment: to select and change illumination lights, music, sounds, visual projections, etc. This audio-visual and cognitive stimulation is a tool which stimulates relaxation and conversation. The training enhances participants' self-awareness, emotional literacy, intellect, social habits, psychological resistance, and creativity. The program includes interactive games, which are suitable for educative classes, raise young visitors' curiosity, simply and attractively present various subjects. Meanwhile, the librarians invite the minors to explore the world of senses. In the long run, it is anticipated that the Space profile will be expanded and transformed into the area of peace and recreation in the Library, where one could find relaxation from the stress of everyday life.

The Library endeavours to keep its main mission, that is, motivation of reading, in particular, among young readers. There are several project exploring how to capture children's interest in books. One of them is a successfully implemented project Knygomanija (Book Mania), thanks to which a new innovative service Sukurk knygos anonsa (Create a Book Trailer) was developed. Applying modern smart technologies, the youths are stimulated to read more, seeking to 
secure development of their visual and critical thinking and personal competences. Working with such new tablets, participants of the classes are given a possibility to try their creative powers and express thoughts about books they have read. It is not a secret that movie trailers encourage them to go to the cinema, and book trailers are one of the best and efficient modern ways to attract and intrigue young readers.

Another project Aš esu knygos herojus (I Am a Hero of the Book) was a successful continuation of Knygomanija. Many people cannot imagine their life without smart technologies, therefore, the Library looks for innovative means to popularize reading and books. The project Aš esu knygos herojus endeavours to intrigue young readers, provide them with more skills to use modern technologies, and also to reveal a still undiscovered interactive side of reading, i.e. to transfer a reader from the position of the plot observer into the magic world of the book and provide him/her with an option to become a hero of the book. The project has been produced for children and youth, who are willing to get involved into the innovative side of reading and, by modern technologies, to be transferred from the observers to book heroes, but who, due to the shortage of information or insufficient financial resources, cannot realize themselves and raise personal competences.

The Library invites its visitors (especially the young generation) to learn and check their knowledge. In order to prove that learning can be playful and not boring, the specialists of the Library have produced interactive tests and puzzles, where one can test his know-how in various subjects. Stressing importance of knowledge about the native country in particular, the Library offers puzzles about Panevėžys and sightseeings in Panevėžys region, as well as persons from Panevėžys well-known worldwide. The interactive screen is available to perform such tests as Lietuvos himnas (The Anthem of Lithuania), Pažink Europos Sajunga (Get Acquainted with the European Union), Ka žinai apie Panevežio apskrities Gabrielès Petkevičaitès-Bités viešąa biblioteka?4 (What do you know about Panevėžys County Gabrielè Petkevičaitė-Bitė Public Library?), Ar pažįsti Panevéži? (Do you know Panevėžys?), etc.

Gabrielè Petkevičaitė-Bitè Public Library provides various services, organizes activities for different age groups, keeps on implementing projects. In order to provide the users, not only in the Library but also at home, with the access to necessary information at any time, and seeking to ensure more effective search

Genovaitė Astrauskienė, „Panevėžio apskrities Gabrielès Petkevičaitės-Bitės viešosios bibliotekos raida”, Žiemgala nr. 2 (2014): p. 18-30. 
in the electronic environment and as continuation of the project Mobilus bibliotekininkas. Nuo stalviršio prie tapšnoklio (Mobile Librarian. From the Desk Top to the Touch Pad) from 2015, a new user service tool - electronic guide (https:// evedlys.pavb.lt) was developed in 2016. Here everyone can find any information about services in the Library, news and events; a thematic visual catalogue with latest and most popular books and their annotations; references to electronic publications; access to the Library's website and sub-websites; calendar of events; references to the databases; electronic catalogue, when connected to it one can order or extend the return term; movietech with trailers of the latest movies available in the Library, and so on. It is also possible to access the website Geros knygos (Good Books), which provides recommendations of readers and the Library personnel about the books they have read. Here can be found the link to the Library's Book Club, which presents books read by its members. One can vote for the favourite books. The website is adapted to mobile devices.

The structure of Gabrielè Petkevičaitè-Bitè Public Library incorporates a unique division, the study centre of legendary theatre director Juozas Miltinis (1907-1994) located in the authentic environment, in the apartment of the director. It also contains a rich private library of Juozas Miltinis, which by his will he has left to Gabrielè Petkevičaitė-Bite Public Library. Taking into account the needs of modern society and with the aim to draw the attention of the young generation to the rich intellectual heritage of the theatre director, the project Režisieriaus Juozo Miltinio palikimas - modernios visuomenés poreikiams (Heritage of the Theatre Director Juozas Miltinis for the Needs of the Modern Society) was implemented in 2018. Thanks to this project, the exposition innovatively and in modern style recreates the theatre magic of the director Juozas Miltinis. The newly designed exposition invites to recollect history of the theatre, using information technologies, to take a look into J. Miltinis personality, life, drama studio, which had functioned in the theatre, to see how a joint creation of the director and the actor, i.e. the performance is born. Every attempt was made to save the content of the director's heritage, erecting the modern exposition, meeting realities of those days, and implementing innovative electronic means, such as information terminal, where the educative contents were selected and presented in the playful manner (quiz), dressed up with permanently renewable and presentable information about the content. With the help of touch screen information terminal, the visitors of the exposition can get acquainted with the illustratively presented history of the theatre, facts from Miltinis life and work, displayed in the time band supported by material cultural values of those days, to receive full information about the content of the displayed exhibits using QR code and NFC, to participate actively in the theatrical education: Teatras yra 
žaidimas (Theatre is a Game), Su režisieriaus Juozo Miltinio legenda į XXI amžiu (With the Legend of Director Juozas Miltinis' into the $21^{\text {st }}$ Century). Modern means are used, and professional performers such as actors, producers, and painters are involved in these activities.

In recent years, the interest in the cultural heritage actualization and digitalization has significantly increased. In 2016, the Library professionals produced the portal Panevezzio kraštas virtualiai (Panevėžys region virtually). ${ }^{5} \mathrm{~A}$ new interactive screen was installed, which presents history of the country and treasures of Panevėžys region to the visitors of the Library in an attractive and modern way, available in the digital format. The control of the touch screen is convenient, images from photos and documents are quality, which can be viewed in a desirable size and resolution, and the content revealing culture of Panevėžys region is comprehensive.

Here you can get the visual and textual information: virtual exhibitions, presentation of new publications, video lectures, browse available portals with valuable digitalized material about culture of the region, including the portal www.epaveldas.It, where publishes digitized archive data, publications, photos, images of pieces of art from Gabrielè Petkevičaitè-Bite Public Library and various Lithuanian institutions, etc.

\section{The Library transforms its physical spaces and infrastructure of services}

After renovation of the building in 2006, Gabrielè Petkevičaitè-Bitè Public Library opened new modern spaces: conference hall with spacious lobby, atrium terrace, space for exhibitions, and visitors' rest area with a small cafe. The Library makes changes and keeps on experimenting. Looking for more interesting solutions, the Library installed in 2017 a multifunctional Cognition Space dedicated to the active rest of families, children and youth. Also, the activities for senior people are arranged there quite often. Since 2018, the Library has been the host of the Inventors' Space, available for young visitors interested in robotics and other technologies. There are working and rest areas on the third floor of the building, where classes and meetings initiated by various Library personnel

Audronė Palionienė, Pristatytas naujas Panevėžio krašto kultūros paveldo portalas [interaktyvus, žiūrèta 2019 m. balandžio 25 d.]. Prieiga per internetą: http://www.jp.lt/pristatytas-naujaspanevezio-krasto-kulturos-paveldo-portalas/. 
take place. There are two book clubs, the English discussion club Let's talk, and the senior people club. The Library becomes more accessible for disabled people. It is the place which hosts a division of the Lithuanian Library Services for the Blind, where persons with vision or other disorders may take home audio books and magazines recorded into MP3 memory sticks. The easily accessible space with a new computerized working place for users with different disorders was established on the first floor of the Library.

A priority of every successful library is promotion of interest in purposeful activities among the young generation. The Open Youth Space operating here arranges discussions for young citizens, invites people to share their histories of success, who have decided to build their future in Panevežys, and, thus, to contribute to recreation of cultural life in the city. The Youth Space is a centre for young people bringing their input into cultural life of the city and promoting activities of the Library. It was a youth by whose initiative the Library began the annual Hario Poterio naktis bibliotekoje (Harry Potter's Night in the Library), ${ }^{6}$ when the Library turns into magic Hogwarts and all participants into young magicians. Each year the repertoire of the Library is complemented by around 100 events produced at the initiative of young people (brainstorms, debates, discussions, creative workshops, table games nights, anime clubs, etc.). It is highly important that the Open Youth Space has inspired love for books in young people and has returned motivation for reading.

\section{Deep traditions of the cultural projects is a visiting card of the Library}

In cooperation with the city development and cultural organisations, since 2011 Gabrielè Petkevičaitè-Bite Public Library has organized annual national festival-contest of sung poetry Mano senas drauge... (My Old Friend...), summoning young song writers and performers from all over Lithuania creating music and singing poetry of the poet Elena Mezginaite. Since 2013, the Library together with its partners - representatives of culture, education, mass media has been implementing the project Jaunųu kürejju galimybiu tribūna "Nevéžis" (The Tribune "Nevežis" for Young Creators' Possibilities), which helps the young creators' from Panevėžys region to reveal themselves in the field of literature and arts and offers a possibility to reach their readers and assessors.

6 „Magiška Hario Poterio naktis”. Sekundè gruodžio 14 (2018): 8. 
Since 1998, the Library has organised the international festival Panevežio literatūrine žiema ${ }^{7}$ (Panevėžys Literary Winter), each time summoning over 80 masters of the words, literary scientists, and music performers from Lithuania and abroad. The event has already developed into the phenomenon not only in Panevezzys city and region, but also in the Lithuanian cultural context. In the program of the festival there is literary and short prose, literary-philosophical debates, photography, painting, music, theatre, installations, etc. Each time in Panevéžio literatūrine žiema we encounter texts in the local dialect. A special award for unexpected debuts is given to young poets and writers from Panevėžys region, i.e. students from secondary schools.

Gabrielè Petkevičaitė-Bite Public Library has been going on with its educative mission from 2010, implementing the reading fostering project Literatüros ir kino dienos (The Days of Literature and Cinema). Reading of Lithuanian literature, creative works of the National Culture and Art Award winners are subtly fostered through literary creations, feature films, and documentaries.

Cultural traditions are also incirporated into the activities of the Library: it has been executing the project Knygos ir biblioteku istorijos raida Panevezzio krašte (Historical Development of the Book and Libraries in Panevėžys Region) since 1998, 19 scientific conferences have been arranged, in which the employees from historical institutions, scientists, heritage researches are invited to discuss not only the traditional studies, changes of their goals and methods, but also the role of genealogy and local history in the network society, involvement of communities, as well as to present actual projects, results and sources of researches in genealogical identities, to have discussions about their access, digitalization, dissemination, and so on. While implementing this on-going project, the Library cooperates with the Communication Faculty of Vilnius University.

Through the cultural and educative activity, the Library unfolds as a space forming civic maturity. The Library, like other institutions of culture and education, starts nurturing public spirit from the youngest visitors, but alongside it finds attractive activity forms for each age group. The greatest activity in this field has been developed by the Library's Juozas Urbšys Public Thought and Cultural Centre, founded in the homestead of the Lithuanian interwar foreign affairs minister Juozas Urbšys. One of the goals of the Centre is to raise a creative person receptive to history, art, and culture of Lithuania. The abovementioned festival-competition of sung poetry and the project of young performers are the activities initiated and performed by the Centre, promoting collaboration of the

„Panevėžyje siaučia literatūrinè žiema”. Sekundè gruodžio 8 (2018): 4. 
creative youth producing the project with a persistent educational value. Another important field of the Centre's activity is the strengthening of historical, ethnic self-consciousness. There is a national contest of essays for older students arranged by the Centre; for the wider population, interested in Lithuanian history, the traditional conferences in August in the memory of the Baltic Road and the Day of the Black Ribbon are organized.

Gabrielè Petkevičaitè-Bitė Public Library deserves every right to be called the centre of culture and arts due to the variety of events: from the book presentations to poetry readings, from concerts of classical music to the modern dance performances. Young people choose meetings with pop music project performers and young writers, the senior audience gives preference to discussions with outstanding public figures, worldwide known countrymen.

\section{Collaboration and volunteering}

The success of many cultural projects is the result of sustainable collaboration. The Library is cooperating with the education institutions of the city, non-governmental organisations, high schools, embassies, etc. The Library is a member of the European Library Cooperation Program NAPLE Sister Libraries, and it signed the agreements with Hueska and Arucas public libraries (Spain). Professional ties have been also confirmed by cooperation agreements with public libraries in Karlovy Vary (Czech Republic) and Rijeka (Croatia).

In recent years, the idea of volunteering has been successfully implemented in the Library. After having volunteering practice, motivated, talented, initiative young people pretty often stay in the Library seeing nice chances to discover themselves and be of use to the society. Having been successfully integrated into the community of the Library, they participate in various activities - conduct trainings, produce movies, represent the Library, implement projects, and so on. Volunteering is a kind of ambassador's mission in the cultural activity of the Library. Being initiators of the events that take place outside the borders of the Library, the volunteers spread good news to the public about the Library's cultural activity, at the same time, attracting more visitors into its space.

The progressive cultural institutions do not limit themselves in the activity, which takes place in their physical spaces. More and more often, museums and libraries are looking for possibilities to bring the cultural news, where their potential visitors meet. Therefore, it is becomming a tradition for the 
Library to participate in the anniversary celebration of Panevèžys city, Night of the Museums, Aukštaitija EXPO, at the international book fair in Vilnius, international tourism and leisure exhibition Adventur, etc.

\section{Conclusions}

There is no doubt that technology has had a lasting impact on libraries. With the help of innovation and vision, libraries are embracing new technologies while creating dynamic community centres filled with life.

Gabrielè Petkevičaité-Bite Public Library aims to harmonize the benefits of advanced technologies and the advantages of traditional cultural projects. The Library's projects for children and youth use gaming to spark youth passion to technology, to stimulate their curiosity and at the same time to maintain interest in books and reading.

The librarians strive to implement innovative ideas that use technology to improve people's lives and to promote lifelong learning, to improve the access to library services for people with disabilities, to foster a sense of public awareness and interest in local history.

Due to education programs based on modern technologies and cultural projects with deep traditions, the Library unites various groups of people: creative youth, adults who are concerned about the current topics of the city, county and country, and inquisitive senior people. 


\section{References:}

1. Astrauskienė, Genovaitè. „Panevėžio apskrities Gabrielès Petkevičaitės-Bitès viešosios bibliotekos raida”. Žiemgala nr.2 (2014): 18-30.

2. „Magiška Hario Poterio naktis”. Sekundè gruodžio 14 (2018): 8.

3. Nauja edukacine erdve socialinès atskirties žmonéms [interaktyvus, žiūrèta 2019 m. balandžio 25 d.]. Prieiga per inernetą: http://www.aina.lt/naujausios-zinios/ nauja-edukacine-erdve-socialines-atskirties-zmonems.

4. Palionienè, Audronè. Pristatytas naujas Panevėžio krašto kultūros paveldo portalas [interaktyvus, žiūrèta 2019 m. balandžio 25 d.]. Prieiga per internetą: http://www. jp.lt/pristatytas-naujas-panevezio-krasto-kulturos-paveldo-portalas/.

5. „Panevėžyje siaučia literatūrinè žiema”. Sekundè gruodžio 8 (2018): 4.

6. Per Lietuva ima ristis Coder Dojo, pasaulinès iniciatyvos, mokančios vaikus programuoti, banga [interaktyvus, žiūrèta 2019 m. balandžio 25 d.]. Prieiga per internetą: https://aina.lt/per-lietuva-ima-ristis-coder-dojo-pasaulines-iniciatyvos-mokancios-vaikus-programuoti-banga/.

7. Ratkutè, Greta. „Projektas, skatinantis pažinti savo kraštą”. Tarp knygu nr. 11 (2018): 11.

8. Švedienè, Virginija. „Kultūros misionieriai”. Tarp knygų nr. 7-8 (2018): 31-33. 


\section{Виргинија Шведиене}

Округ Паневежис

Народна библиотека „Габриеле Петкевичаите-Бите”, Литванија

virginija.svediene@pavb.lt

\section{НАРОДНА БИБЛИОТЕКА „ГАБРИЕЛЕ ПЕТКЕВИЧАИТЕ- -БИТЕ”: ИНОВАТИВНО И ТРАДИЦИОНАЛНО}

Сажетак: Народна библиотека „Габриеле Петкевичаите-Бите” у Паневежису, највећа јавна библиотека у североисточном региону Литваније, прославила је своју 95. годишњицу 2017. године. Централна је библиотека у овом региону са највећим универзалним фондом, позната по традицији успешних културних пројеката. Важан је регионални центар културе и образовања. Визија библиотеке је модеран центар библиотечких иновација у региону, који пружа атрактивно окружење и једнаке могућности за учење и стварање. Библиотека данас посебну пажњу посвећује развоју квалитетних образовних програма и њиховој примени на различите старосне групе. Један од главних приоритета је побољшање дигиталне писмености, али без губитка крајње мисије библиотеке, тј. промоције читања. Библиотека ствара просторе привлачне за изражавање креативности корисника, где се традиционалне активности и образовање засновано на модерним технологијама складно уклапају.

Кључне речи: Литванија, библиотека, иновације, традиција, образовање.

Примљено: 8. априла 2019. Исправке: 29. априла 2019. Прихваћено: 6. маја 2019. 